characters, at least in variabilis, are subject to great variation. A recent examination of the types and of the series both at the Gipsy Moth Parasite Laboratory and at the United States National Museum by the writer brings out two points, i.e., that the species are abundantly distinct and that the pollinosity on the third segment of the abdomen in variabilis varies all the way from the typical condition to the condition met with in typical floridensis. The following conspicuous structural differences will serve to separate the species :-

\section{T. variabilis Coq.}

I. Third joint of antennæ 3.5 to 4 times lengih of 2 nd.

2. Costal spine very inconspicuous.

\section{T. floridensis Tn.}

I. Third joint of antennæe 2 to 2.5 times length of 2 nd.

2. Costal spine strongly developed and very conspicuous.

(To be continued.)

\title{
NOTES ON THE PARASITIC HYMENOPTERA.
}

BY A. A. GiRAUlt, BRisbane, AUStralia.

Superfamily Chalcidoidea.

Family Encyrtidæ.

Subfamily Encyrtinæ.

Tribe Arrhenophagini.

Genus Rhopoideus Howard.

I. Rhopoideus fuscus, new species.

Dr. C. Gordon Hewitt, Dominion Entomologist, Ottawa, Canada, has sent me among other things eight specimens of an Encyrtine bearing acute edentate mandibles, which agree well with the genus Rhopoideus Howard. This species, however, has but 9-jointed antennæ, counting a very short, almost imperceptible ring.joint; its antennal club is solid. Now Ashmead gives as a diagnostic character of the genus in question Io-jointed antennæ (the funicle 5-jointed, no ring-joint mentioned), which would imply at least a 2 -jointed antennal club. The original description of Rhopoideus leaves one in doubt as to the total number of antennal joints, the only statement made concerning them being to the effect that the funicle is 5 -jointed. Nevertheless, this Canadian species agrees so well with the generic description, even to the possible hosts, except in the antennæ, that we have reason to question Ashmead's statement concerning the latter. With this species the funicle is 5 -jointed, the first three joints 
"small and narrow, each rather broader than long, 4 and 5 broader and longer and as broad as long," as described for the type species, except that in each case here the joints are longer than wide. The antennæ of this species appear to agree in general form with those of the type of Rhopoideus.*

Female.-Length, I.95 mm. Rather long and slender, the body flattened or depressed.

General colour uniformly brown, but the abdomen somewhat paler, the brown emphasized along the caudal margins of the segments (making at least four transverse brown stripes across the abdomen, which, however, are not conspicuous). Antennæ concolorous; legs somewhat lighter, with some yellow, the tarsi pallid yellowish, the distal tarsal joint clouded. Eyes dark. Wings hyaline, with the exception of a slight cloud of fuscous under the stigmal vein and just out a slight distance from the base, and also sometimes slightly touched with fuscous along the caudal margin irregularly, proximad and along the obl:que hairless line at either margin of it. Trochanters and bulbs of the antennæ pallid.

Mesoscutum and mesoscutellum polygonally sculptured, as if covered with flat scales, both bearing a few, sparse, short setæ; the concave face finely lined with circular lines (concentric about the rather deep and large, crescentic scrobicular cavity in about the centre of the face); carina of vertex present; tarsi 5 -jointed, the joints short yet longer than wide; tibial spurs single, the cephalic spur curved and forked at tip; caudal femora somewhat thickened, legs otherwise slender or usual. Fore wings with an oblique, hairless line running proximo-caudad from the origin of the stigmal vein. Mandibles short, claw-shaped, acute and edentate at tip. Submarginal vein long and slender, the costal cell rather wide, the marginal vein a mere rounded point where the submarginal touches the cephalic margin, the postmarginal vein absent, the stigmal vein distinct, moderate in length, with a slender neck. Fore wing (including the costal cell) denstly, finely ciliated, the blade ample and wide, only about twice longer than broad, the marginal cilia short, becoming noticeable only at apex and disto-caudad, where they are moderately shoit. Caudal wings densely ciliate discally, rather short. Parapsidal furrows absent. Abdomen

${ }^{*}$ Dr. L. O. Howard has very kindly examined the type of his Rhopoideus citrinus for me, and tells me in a letter dated Augu it 8, I9I I, that the antennal club of that species is solid, hence the antennæ 8-jointed (excluding any question of a ring-juint). Ashmead's diagnosis of the genus is therefore wrong. 
longer than the thorax, cylindrical but pointed at the apex, the valves of the ovipositor slightly extruded. Ocelli in a slightly curved line. Scutellum peltate, angular, as wide as long or nearly. Cephalic aspect of head nearly quadrate.

Antennæ 9-jointed; scape long and slender, slightly thickened in the middle, the bulb rather long, both together over twice longer than the pedicel; the latter obconic, rather long, over twice longer than wide; a very flat, short ring-joint, which has the shape of a mushroom; funicle joints $x-3$ short, 4 and 5 longer and wider; 1 and 2 subequal, each slightly longer than wide; 3 of same width but slightly longer; 4 a third longer and broader than 3 ; and 5 a third longer and broader than funicle joint 4 ; all much shorter than the pedicel, which is subequal in length to the combined lengths of the first three funicle joints; club solid, long and cylindrical, obtusely pointed, not quite as long as the funicle. Pubescence of antenna short, not dense or conspicuous.

(From eight specimens, 2/3-inch objective, I-inch optic, Bausch and Lomb.)

\section{Male.-Unknown.}

Described from eight specimens mounted singly on slides, received for identification from Dr. C. Gordon Hewitt, as noted above, each slide labelled "from spruce budworm material, Province of Quebec," and respectively, "Maniwaki, 27, VI, I I," and "Montcalm, 6, VII, I I," two females, two slides (homotypes in Canada); "Chicoutimi, 3, VII, I I," and "St. Gabriel de Brandon, 3, VII, I I," two females, two slides co-types, as noted below); "Chicoutimi, 3, VII, I I," and "Montcalm, 6, VII, I I," two-females, two slides (types); and "Chicoutimi, 3, VII, I I, two females, two slides (homotypes in collection Illinois State Laboratory of Natural History). The supposed host is Tortrix fumiferana Clemens, but a coccid is indicated instead. Other coccid parasites, some noted beyond, were reared from the same host material.

Habitat.-Dominion of Canada-Quebec (Chicoutimi, Maniwaki, Montcalm and St. Gabriel de Brandon).

Types.-Cat. No. 14,206, United States National Museum, Washington, D. C., the two females as indicated above. Co-types: Accession No. 45,080, Illinois State Laboratory of Natural History, Urbana, U. S. A., the two females, two slides as indicated above. Homotypes: The two females as above indicated, in the collections of the Division of Entomology, Central Experimental Farm, Ottawa, Canada, and the two 
indicated as being in the collections of the Illinois State Laboratory of Natural History (Accession No. 45,085).

This species evidently differs considerably from the type species, citrinus Howard; it must be considerably larger and more slender, the colour is brown, not light orange; the mesonotum is differently sculptured, namely, polygonally, not finely, transversely lined; the sheaths of the ovipositor not nearly black at tip but concolorous; the joints of the funicle somewhat longer, and the antennal club shorter, not as long as the funicle, even; and no oblique hairless line on the fore wing is noted for the type species, nor a ring.joint in the antennæ.

Family Pteromalidæ.

Subfamily Sphegigasterinæ

Tribe Sphegigasterini.

Genus Urios Girauit MS.

\section{Urios vestali Girault.}

This nearly wingless species, which was described in the Journal of the New York Entomological Society (December, I9II), was captured by Mr. A. G. Vestal at the Devil's Hole, near Havana, Illinois. It was found in an ant's nest (Pheidole vinelandica Forel.), April I, rgr I. The nest of the ánt was in sandy soil, in a bunch grass area. Mr. Vestal stated that, casually, he was unable to distinguish the pteromalid from the ants. In other word; it closely mimics the host ant.

Family Eulophidæ.

Subfamily Entedoninæ.

Tribe Omphalini.

Genus Astichus Foerster.

I. Astichus bimaculatipennis, new species.

Normal position.

Female.-Length, r. $85 \mathrm{~mm}$. Funicle not ringed with white, scutellum not smooth, and without grooved lines, parapsidal furrows not very distinct, cilia of wings not in rows, dense; wings with two maculæ. Species large for the genus.

General colour metallic green, the hexd and pronotum metallic bluish, the face æneous. just dorsad, purplish just ventrad, of the insertion of the antennæ; the dorsum of the abdomen, except the metallic green proximal segment, dark, purplish black; metanotum with æneous reflections ; scape pallid dusky; thoracic pleura and coxæ metallic dark bluish, the femora 
the same, pallid at apical end; trochanters dark; tibiæ and tarsi pallid, the apical tarsal joint dark or black ; flagellum dusky; ventum of thorax and abdomen dark, purplish black. Tegulæ dark. Wings hyaline, venation dusky, the fore wing with two dusky blotches along the cephalic or costal margin, the first or proximal one at the junction of the submarginal and marginal veins, rounded and about one-half the size of the apical one, which is situated at the stigmal vein, and is more irregular in outline. Eyes chestnut red; ocelli ruby red.

Head flat from lateral aspect, the occipital margin acute; front broad, concave, vertex narrow, broader laterad; eyes lateral, oval, covering a little over a half of the lateral aspect of the head, the malar space present; antennæ inserted, about on an imaginary line drawn between the ventral ends of the eyes, the scape not reaching to the vertex; lateral ocelli on the narrow vertex at the occipital margin, distant from the eyes, but farther apart from each other than each is from the eye margin, dorsal, an imaginary line connecting them convex; the cephalic ocellus barely visible from dorsal aspect, cephalic, forming a flat triangle with the others, and situated in the cephalic aspect of the vertex front, against the acute occipital marg!n at the meson and closer to the lateral ocelli than they are to each other. Head delicately shagreened, its surface not as coarse as the surface of the eyes; the entire thorax dorsad moderately, coarsely, polygonally reticulated, the parapsidal furrows mere impressions, inconspicuous, not well defined grooves, and from some aspects seen only caudad; pronotum visible from dorsal aspect, about one-third the length of the mesocutum, the caudal margin of the latter, between the advanced axillæ, convex; scutellum rounded, normal, convex, without grooved lines; mesopostscutellum not large, crescentic, sculptured like the scutellum; metathoracic spiracle margined, distinct, short and broadly oval; metathorax slightly more delicately sculptured than the scutellum and scutum of the mesothorax, and with a delicate median carina, and two others, on each side of the meson, both curved and running caudolaterad from the caudal margin of the mesopostscutellum; of these two lateral carinæ, the more laterad or cephalic one is the shorter. Coxæ and the thoracic pleura sculptured similarly to the metanotum, the cephalic coxæ less so; caudal coxæ enlarged, subtriquetrous. Abdomen conicovate, but very slightly produced or convex ventrad, longer than the head and thorax combined and than the wings; very delicately reticulated. 
Fore and hind wings densely ciliate discally, the cilia short and close; marginal cilia of both wings short and close, longer on the hind wings. Marginal vein of fore wings subequal to or slightly shorter than the submarginal vein, the postmarginal vein equal to half the length of the marginal, and nearly twice the length of the stigmal vein, which is bifurcate at apex.

Antennæ filiform, not very long, the scape cylindrical and of moderate length, the funicle 4 -jointed, the club 3 -jointed, and with a single ring-joint. Pedicel small, obconic, about a third of the length of the long first funicle joint; ring-joint minute; first funicle joint cylindrical, the longest antennal joint, wider than the pedicel and a fourth longer than the following joint; funicle joints 2 and 3 subequal, cylindrical oval, joint 2 slightly longer and slightly narrower than joint 3 , and both distinctly shorter and broader than joint $\mathrm{I}$ of the funicle; funicle joint 4 subquadrate, of about the same width, but only about two-thirds of the length of joint 3 ; proximal club joint large, half the length of the club, but distinctly smaller than the apical funicle joint ; the intermediate club joint smaller, conical, not much larger than the pedicel, about a little over half the size of the proximal club joint ; the apical or discal joint minute, nipple- or spur-like. Funicle and club hispid, with white hairs, of which there are about three transverse rows on the first funicle joint, and two rows on each of the following funicle joints and the proximal club joint.

(From a single specimen, $2 / 3$-inch objective, 2 -inch optic, Bausch and Lomb.)

\section{Male-Unknown.}

Described from a single female specimen received for identification from Mr. R. L. Webster, Iowa College of Agriculture and Mechanic Arts, Ames, Iowa, who reared it as a probable hyperparasite of Alceris minuta Robinson. (Bull. No. Io2, Iowa State College of Agriculture and Mechanic Arts Experiment Station, Ames, Iowa, p. 2 Io.)

Habitat.-United States, Ames, Iowa.

Type.-Accession No 40,290, Illinois State Laboratory of Natural History, Urbana, one female on a tag, plus one balsam slide with antennæ.

Subfamily Aphelininæ.

Tribe Aphelinini.

Genus Physcus Howard. 


\section{Physcus varicornis Howard.}

I desire to record the occurrence of this coccid parasite in some Canadian localities. Dr. Hewitt recently sent me four female specimens on slides labelled "From spruce budworm material, Maniwaki, Montcalm and St. Gabriel de Brandon, Province of Quebec, 2, 3 and 6, July, I 9 I I."

In the original description of this genus (Howard, Bull. No. I, technical series, Division of Entomology, U. S. Department of Agriculture, 1895, p. 43), a statement is made to the effect that the "second and third funicle joints " are "subequal and each longer than joint r." Later (Id., Bull. No. I 2, technical series, Bureau of Entomology, U. S. Department of Agriculture, 1907, p. 72), this statement is used as a diagnostic character in a table of genera to the Aphelinini. The character varies. In the four specimens noted above, three have the joint as described, but the fourth specimen has the first funicle joint slightly longer than either joint 2 or 3 . In some Illinois specimens I have noted the same variation, sometimes all three joints equal, sometimes the second shortest, and in others as described originally. The matter is of no great importance, since the table mentioned can do without the line containing the statement about the funicle joints. The variation itself, however, is a rather peculiar one, and important from the standpoint of specific characters.

\section{Genus Prospaltella Ashmead.}

\section{Prospaltella aurantii (Howard).}

This widely distributed parasite of coccids has lately been received from Dr. Hewitt from several localities in Canada, which I think should be recorded in this connection. There were seven females on six slides labelled "From spruce budworm material, Chicoutimi, St. Gabriel de Brandon and Maniwaki, Province of Quebec, July 2 and 3, I9 Ir." They evidently originated from some coccid concealed in the host material. All of the specimens were compared with the type, and are homotypes, therefore. The fore wings in this species seem to have a tendency to be very slightly clouded out to the end of the marginal vein from base, but this cloudiness is so slight that one cannot always be sure that it is real. From the collections of the United States Department of Agriculture I have a series of six females on a slide, with a number of other coccid parasites labelled "I 725. Aspidiotus on common wild shrub on streams, California and Cuautla, Morelos, Mexico, July r, '97, Koebele." 
I have also seen two other series of this species from Mexico, on slides from the same collection, which evidently form a distinct race of aurantii, and which I thought at first would certainly prove to be specifically distinct. This form differs in having distinctly broader fore wings (about from 19 to $2 \mathrm{I}$ lines across the widest portion of the blade, aurantii bearing only about I $_{5}$ ), their longest marginal cilia less than a third of the greatest width (in the type form over a third), and the antennæ differing in that each joint of the funicle is longer than the one preceding, the third longest; whereas in the type form the second joint is l.nngest. I have no doubt but that these forms grade into each other. The specimens should be recorded. They are: Three females on a slide with Signiphora libelled "I 745. Aspidiotus on soft wooded fibrous tree. Cordoba, Mexico, I 7, 7, '97, Koebele"; and thirteen females on a single slicie, with several species of Signiphora (mexicana Ashmead, flavopalliata Ashmead, and townsendi Ashmead), together with an Ablerus, labelled "1768. Aspidiotus on Hibiscus, Cuautla, Morelos, Mexico, May 29, '97, Koebele." These last specimens varied in colour, most of them having the abdomen wholly black-brown instead of brownish yellow.

\section{FURTHER NOTES ON DIABROTICA. \\ No. II.}

BY FRED. C. BOWDITCH, BROOKLINE, MASS.

(Continued from Vol. XLIII, page 4I7.)

D. boucardi, nov. sp.

Head, thorax and scutel smooth shining black; antennæ and feet fuscous yellow; elytra bright purpie, lateral margin obsoletely viridescent, with two transverse depressions and also humeral and lateral submedian impressions. Length $7 \mathrm{~mm}$.

One example, Panama, in the Boucard collection of the Tring material;

Belongs in sec. D, near coccinea Baly. The palpi are the colour of the antennæ; head with a deep frontal puncture; antennæ more than half as long as body, 2nd joint short, 4 much longer than 3 . Thorax elongate, sinuate and sharply angled behind with a deep transyerse depression, occupying the rear half; elytra somewhat dilated at the rear; the ISt transverse impression is at the rear of the anterior third, the 2 nd is much the larger of the two and occupies the middle of the elytra, the two connected by a depression along the suture; the humeral depression is slightly curved inwards and ends about the beginning of the middle third 


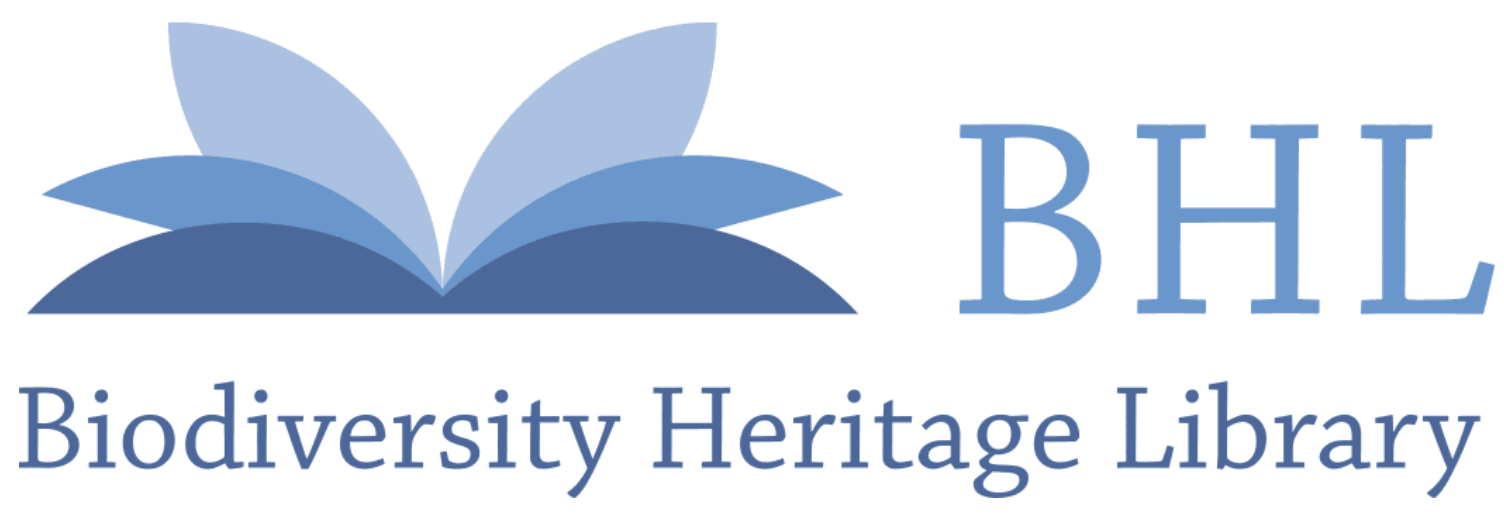

Girault, Alexandre Arsène. 1912. "Notes on the parasitic Hymenoptera." The Canadian entomologist 44, 5-12.

View This Item Online: https://www.biodiversitylibrary.org/item/31539

Permalink: https://www.biodiversitylibrary.org/partpdf/39596

\section{Holding Institution}

MBLWHOI Library

\section{Sponsored by}

MBLWHOI Library

\section{Copyright \& Reuse}

Copyright Status: NOT_IN_COPYRIGHT

This document was created from content at the Biodiversity Heritage Library, the world's largest open access digital library for biodiversity literature and archives. Visit BHL at https://www.biodiversitylibrary.org. 